\title{
Formation of the vegetation cover in the desert pasture phytocenoses
}

\author{
Khusen Khamroyev ${ }^{1}$, Obidjon Abdullayev ${ }^{2 *}$ \\ ${ }^{1}$ Tashkent State Agrarian University, 100140 Tashkent, Uzbekistan \\ ${ }^{2}$ Research Institute of Forestry, 111104 Tashkent, Uzbekistan
}

\begin{abstract}
Rising global temperatures in recent years have led to a sharp increase in the area of desert areas. Desert areas are widely used as pastures. The productivity of desert pastures in Uzbekistan is very low, ie 1-3 ts/ha. This limits the year-round use of desert pastures. One of the resource-saving and long-term effective ways to increase their productivity is to plant enclosures, as well as reclamation and forage rows in these desert pastures using plants such as Haloxylon aphyllum, Calligonum caput-medusae, Salsola paletzkiana. This is because protected areas have been scientifically proven to show their positive properties in other areas (around mountainous and irrigated fields). In these areas, enclosures not only perform a protective function, but also serve as a source of fodder for livestock in the autumn-winter seasons.
\end{abstract}

\section{Introduction}

Pasture is one of the most important sources of fodder for livestock. Pastureland varies from country to country, with 362.3 million hectares in Australia, 256.0 in the United States, 23.1 in Spain, 20.8 in Canada, 12.6 in New Zealand, 12.5 in the United Kingdom, 12.3 in France, and 5.2 in Poland and 5.2 in Italy [1]

Pastures in the CIS countries are divided into perennial grasses (tundra) pastures and bush and shrubs (tundra, semi-desert and desert) pastures, depending on the vegetation cover. The duration of grazing also varies in these pastures ranging from 125-150 days in the forest zone, 170 days in the forest-desert zone, and 200 days in the desert zone [2].

In recent years, a lot of research has been conducted by foreign scientists on the condition of pastures and increasing their productivity [3,4]. In particular, Russian scientists have studied the condition of pastures in Gomel, Moscow, Novosibirsk, Voronezh, NorthWestern Caspian regions, and noted that cereals and legumes form the main phytomass in these areas [5].

Desert plants grow well even in severe xerothermal conditions [6], desert pastures provide cheap fodder, are suitable for year-round use; have high variability and diversity of nutrient levels. One of the disadvantages of these pastures is their low yield (1-3 ts/ha dry mass), seasonality and rapid change of yield throughout the year [7]

In different countries of the world, pastures are used as a source of fodder of great importance for livestock [8]. At present, some of the most pressing issues are the efficient

* Corresponding author: obidjonabdullayev.90@mail.ru 
use of pastures, increasing their productivity and expanding the composition of varieties and forms of forage plants, development of maintenance agrotechnics, increasing of forage species types in pastures, and mixed plantings [9]. Whereas in the world's leading pasture research centers, scientifically proven ways to increase pasture productivity were developed, such as using trees and bushes in the United Kingdom, legumes and cereal plantss in Switzerland, Artemesia ordosica L. in China, Brazos sort and Lolium multiflorum, Festuca elatior cross-breeds of tropical legumes in Japan, in Estonia it was achieved to increase the pasture productivity to $6630 \mathrm{~kg} /$ ha in average mainly by using five to seven plant species. In the indigenous pastures of Bolivia, Brazil, Colombia and Venezuela, work has been carried out to increase pasture productivity by sowing seeds of plants (legumes and cereals) introduced using special agro-technical methods (mineral fertilization, regeneration). The results obtained on the basis of these scientific developments are important in increasing the productivity of pastures, both theoretically and practically $[10,11]$.

Artemisia ordosica has been widely used in sand fortification in China, as its share in the main biomass of pastures in this region is large [12].

Due to the sharp decline in productivity in Mongolia in the summer, the number of large livestock has declined sharply, and to prevent this, agro-technical cultivation of pastures has been carried out [13].

In Bolivia, Brazil, Colombia and Venezuela, 55-65\% of the area is natural pasture, and special agro-technical methods (mineral fertilization, rehabilitation, sowing of introduced crops (legumes and cereals)) have been used to increase pasture productivity [14].

The unfavorable summer climate in Japan has been observed to adversely affect the growth of legumes and cereals, causing them to dry out quickly. Positive results were obtained using hybrids of tropical legumes Brazos, Lolium multiflorum, Festuca elatior to increase productivity [15].

\section{Materials and Methods}

The research was carried out at the Bukhara State Forest Experimental Station, located in the southern part of the Kyzylkum Desert in the Jondor district of Bukhara region, which belongs to the Research Institute of Forestry. Formation of vegetable cover on the desert of phytocenoses was studied on the basis of the method outlined in the manual by I.F Momotov "Theoretical foundations and methods of phytomelioration of desert pastures" In the object, changes in soil microclimate under the influence of enclosures, phytocenosis composition, cultivated and wild plants in rows, 4 natural and 10 artificial phytocenoses built on different soil types, as well as changes in the productivity of natural and artificial phytocenoses as a result of various external adverse factors were studied. 10 experimental sites, 34 transects with a total area of 3.5 thousand $\mathrm{m}^{2}, 200$ experimental sites for plant studies, 150 experimental sites for plant growth and development were selected for the observations. To identify the difference from the other areas, 4 test transects measuring 50x2 m were selected. In each trancect 3 times a year - in spring, summer and autumn - a general calculation of the species and quantity of plants was carried out.

In order to record the life phenophase and condition, the height and crown diameter were measured to the nearest $1 \mathrm{~cm}$ in both directions. The number of ephemerals was usually counted at $1 \mathrm{~m}^{2}$ of experimental sites. The growth and development of forest plants in the reclamation-forage and pasture protection rows, which are part of the phytocenosis, were determined at a length of $4 \mathrm{~m}$ from the experimental sites. Every year during the vegetation season, the plants were classified and recorded as large, medium and small species depending on the crown height and diameter. 


\section{Results and Discussion}

The vegetation cover in the phytocenoses studied varied during development processes. Concurrently, the condition of the plants that form the local flora improved, and their density and quantity increased. The number of species increased also due to shrubs, semishrubs, annuals and perennials. In the spring, ephemeral and ephemeroids, with Bromus tectorum as a dominant, formed and prevail. Observations revealed that the amount of plants in the spring was 1.1-9.8 times higher than the test case (Fig. 1). Condition of the patures protected by enclosures and the condition of the natural pastures around it is shown in Fig. 2.

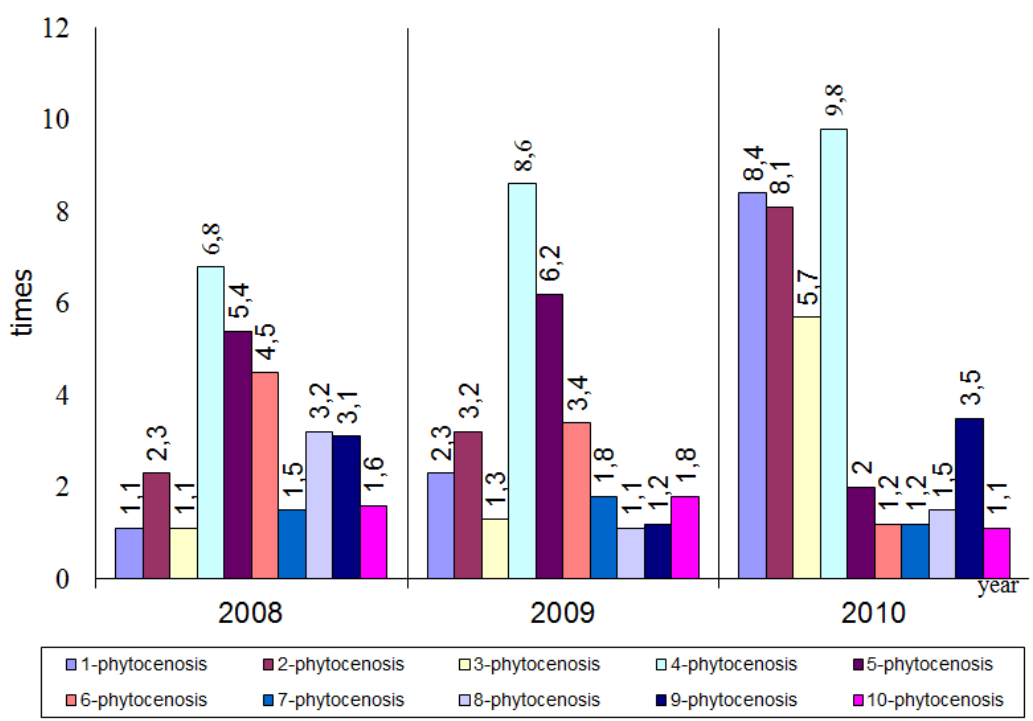

Fig.1. Increase in the number of spring plants in phytocenoses relative to natural pastures, times

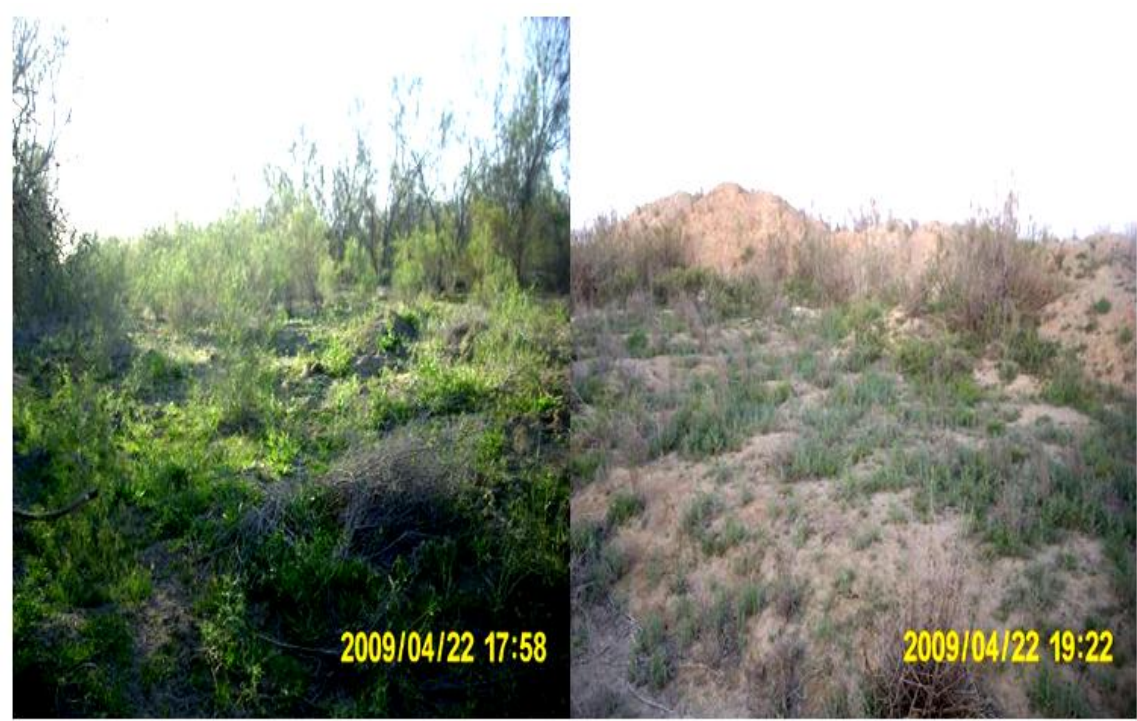

Fig.2. Condition of the patures protected by enclosures and the condition of the natural pastures around it 


\section{ICECAE 2021}

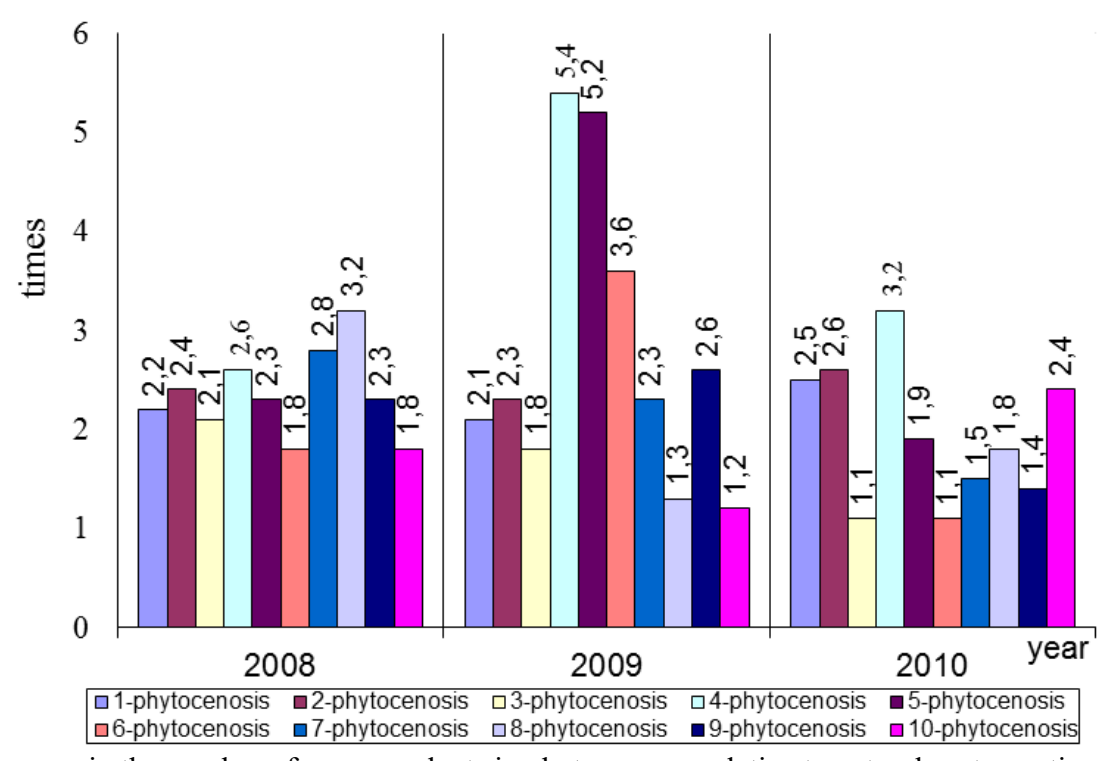

Fig.3. Increase in the number of summer plants in phytocenoses relative to natural pastures, times

In summer, 1 st phytocenosis in barren soils $(2.1-2.5$ times $), 2^{\text {nd }}$ phytocenosis in sandy soils with weakly developed grass cover $(2.3-2.6$ times $)$ and $3^{\text {rd }}$ phytocenosis in sierozem soils (2.6 - 5.4 times) were higher than other phytocenoses (Fig. 3).In autumn, the number of plants was mainly bushes, shrubs and perennial grasses. This season, as a result of enclosures impact, the amount of vegetation was 1.3-13.7 times higher compared to the test case. The main reason for the high number of plants compared to the test case was the sharp increase in air temperature $\left(45^{\circ} \mathrm{C}\right)$ in July-August and the loss of moisture in the soil layer. This season, too, the above-mentioned indicators in the phytocenoses were higher than others (Fig. 4)

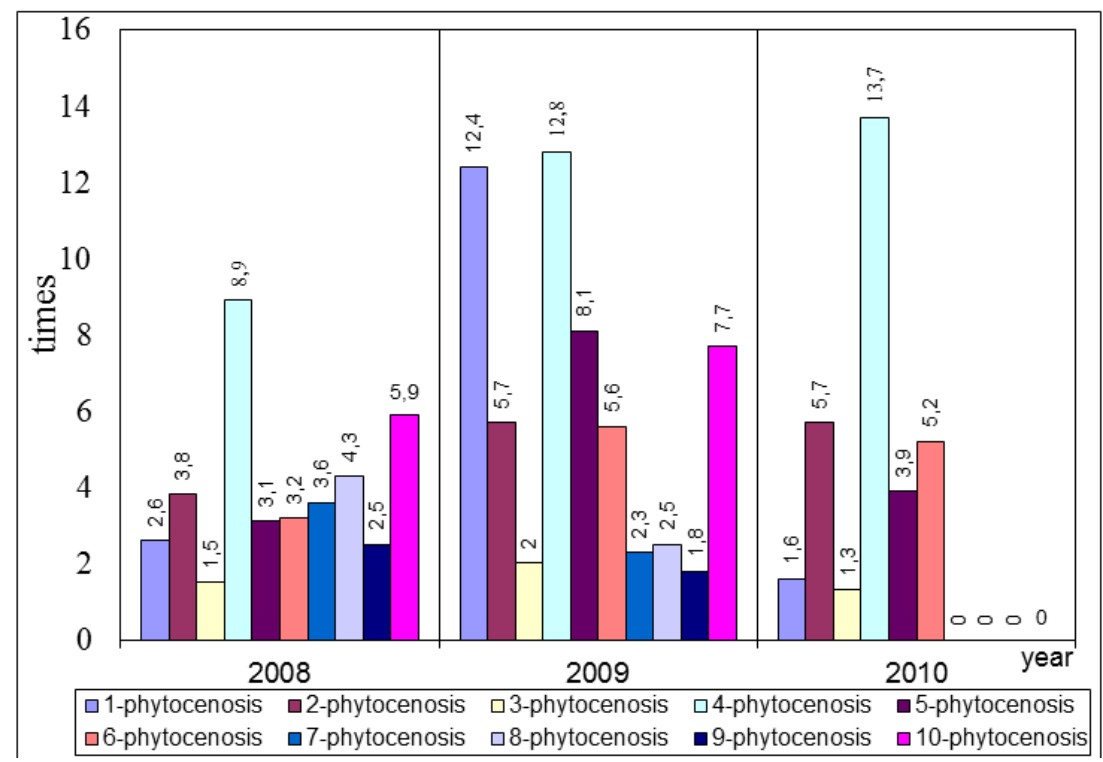

Fig.4. Increase in the number of autumn plants in phytocenoses relative to natural pastures, times 
Annual herbaceous plants played an important role in the formation of the first phytocenosis. In the spring of 2008, the number of plants exceeded the test case by 1.1 times, in 2009 by 2.3 times, and in 2010 by 8.4 times. The level of vegetation cover of the soil surface also changed in proportion to the number of plants, which was 2.6-7.9 times higher than the test case.

\section{Conclusions}

The formation of pasture phytocenoses depends on the establishment of protective and reclamation-forage rows. This is due to the fact that under the influence of enclosures, favorable conditions are created for the growth and development of plants.

Numerous promising fodder crops have been studied for the establishment of enclosures and reclamation-forage rows in the Southern Kyzylkum conditions, and Haloxylon aphyllum, Halothamnus subaphyllus were indicated as primary, Salsola richteri, Ceratoides eversmanniana, Salsola orientalis, Kochia prostrata, Calligonum caput-medusae were indicated as secondary crops. They grow intensively, are deep-rooted, able to reduce selfevaporation, are resistant to high temperatures of soil and air even when moisture reserves in the soil are limited, and maintain viability even when moisture is lost in the leaves.

\section{References}

1. E.R. Sharma, D.B. Amatya, Degradation of forest resources in Nepal, The Nepal Journal of Forestry 1, 74-81 (1978)

2. A. Movsisyans, Pastures, use of pastures, Science, Moscow (1969).

3. T. Atsbha, A. Estifanos, T. Tesfay, S. Wayu, A. Baraki, Improving the Productivity of Degraded Pasture Land Through Legume Forages over Sowing, International Journal of Science, Technology and Society 5(3), 33-36 (2017)

4. J. Orefice, R.G. Smith, J. Carroll, et al., Forage productivity and profitability in newlyestablished open pasture, silvopasture, and thinned forest production systems, Agroforest Syst 93, 51-65 (2019)

5. S.R. Khalikov, O.V. Skidan, V.M. Mikityuk, Directions for the development of pasture animal husbandry in Ukraine, International Conference on Scientific Basis of Rational Use of Pastures, Tashkent State Agrarian University, Tashkent (2009)

6. W. Alsharif, M.M. Saad, H. Hirt, Desert Microbes for Boosting Sustainable Agriculture in Extreme Environments. Frontiers in Microbiology 11, 1666 (2020)

7. C. Pornaro, V. Vincenzi, S. Furin, M. Fazzini, L. Minarelli, S. Macolino, Seasonal changes in dry matter yield from Karst pastures as influenced by morphoclimatic features, PLoS ONE 13(9), e0204092 (2018)

8. F.P. O'Mara, The role of grasslands in food security and climate change. Annals of Botany 110(6), 1263-1270 (2012)

9. N.M. Capstaff, A.J. Miller, Improving the Yield and Nutritional Quality of Forage Crops, Frontiers in Plant Science 9, 535 (2018)

10. E. Anu., V. Risio, Local and regional processes in low-productive mountain plant communities: The roles of seed and microsite limitation in relation to grazing, Oikos $\mathbf{2}$, 360-368 (2005)

11. V. Rein, K. Niina, P. Argaadi, S Are, K. Lagle, Seemnesegu koosselsu moju seguk Lulvide saagile, Trans- Tartu 220, 129-131 (2005)

12. Q.Wang, B. Li, Preliminary data from studies on the biomass of Artemisia Ordositsa in communities in the sandy lands of the Ordos Plateau in China, Zhiwu Shengtai Xuebao 4, 347-353 (1994) 
13. B. Bolortsetseg, G. Tuvaansuren, The potential impacts of climate change on pasture and cattie production in Mongolia, Water, Air, and Soil Pollut. 1(2), 95-105 (1996)

14. G. Rippstem, C. Lascano, T. Decaens, La production fourragere dans les savanes d'Amerique du Sud intertropicale, Fourrages 145, 33 -52 (1996)

15. N. Kaushal, K. Bhandari, K.H.M. Siddique, H. Nayyar, Food crops face rising temperatures: An overview of responses, adaptive mechanisms, and approaches to improve heat tolerance, Cogent Food \& Agriculture 2, 1 (2016) 